\title{
Potentiometric Aptasensing of Vibrio alginolyticus Based on DNA Nanostructure-Modified Magnetic Beads
}

\author{
Guangtao Zhao ${ }^{1,2,+}$, Jiawang Ding ${ }^{1,+}$, Han Yu ${ }^{1,2}$, Tanji Yin ${ }^{1, *}$ and Wei Qin ${ }^{1, *}$ \\ 1 Key Laboratory of Coastal Environmental Processes and Ecological Remediation, \\ Yantai Institute of Coastal Zone Research (YIC), Chinese Academy of Sciences (CAS); \\ Shandong Provincial Key Laboratory of Coastal Environmental Processes, YICCAS, Yantai 264003, \\ Shandong, China; gtzhao@yic.ac.cn (G.Z.); jwding@yic.ac.cn (J.D.); hyu@yic.ac.cn (H.Y.) \\ 2 University of Chinese Academy of Sciences, Beijing 100049, China \\ * Correspondence: tjyin@yic.ac.cn (T.Y.); wqin@yic.ac.cn (W.Q.); Tel.: +86-535-210-9156 (W.Q.) \\ + These authors contributed equally to this work. \\ Academic Editor: Huangxian Ju \\ Received: 23 September 2016; Accepted: 28 November 2016; Published: 2 December 2016
}

\begin{abstract}
A potentiometric aptasensing assay that couples the DNA nanostructure-modified magnetic beads with a solid-contact polycation-sensitive membrane electrode for the detection of Vibrio alginolyticus is herein described. The DNA nanostructure-modified magnetic beads are used for amplification of the potential response and elimination of the interfering effect from a complex sample matrix. The solid-contact polycation-sensitive membrane electrode using protamine as an indicator is employed to chronopotentiometrically detect the change in the charge or DNA concentration on the magnetic beads, which is induced by the interaction between Vibrio alginolyticus and the aptamer on the DNA nanostructures. The present potentiometric aptasensing method shows a linear range of $10-100 \mathrm{CFU} \mathrm{mL} \mathrm{m}^{-1}$ with a detection limit of $10 \mathrm{CFU} \mathrm{mL}^{-1}$, and a good specificity for the detection of Vibrio alginolyticus. This proposed strategy can be used for the detection of other microorganisms by changing the aptamers in the DNA nanostructures.
\end{abstract}

Keywords: potentiometric aptasensing; Vibrio alginolyticus; DNA nanostructures; magnetic beads; protamine

\section{Introduction}

As an opportunistic marine pathogen, Vibrio alginolyticus (V. alginolyticus) can not only lead to septicemias and corneal opaqueness in fish and shell diseases and white spots in shrimps [1-3], but also infects mammalian cells causing otitis, wound infection, and chronic diarrhea [4,5]. The rapid and sensitive detection of $V$. alginolyticus is of great importance for aquaculture, food industry, and clinical diagnosis.

The agar plate culture method and enzyme-linked immunosorbent assays are commonly used for the detection of bacteria. However, they suffer from such problems as time-consuming procedures, false-positive signals, low sensitivity, and poor specificity [6]. The polymerase chain reaction (PCR) technique, especially for the multiplex PCR, has been developed for the detection of bacteria with good specificity and high sensitivity [7-10]. However, this technique needs complex pretreatment procedures and expensive instruments.

Aptamers are single-stranded DNA or RNA oligonucleotides designed through the systematic evolution of ligands by exponential enrichment. Since aptamers have high specificities and binding affinities to their targets, they have been widely used to develop a variety of electrochemical biosensors for the detection of small molecules, metal ions, and proteins [11-15]. Nowadays, aptamers have 
also been used for the detection of bacteria based on their high specificity bindings to proteins either on the cell surfaces or inside the cells [16-19]. Various electrochemical aptasensors using different transduction modes such as amperometry, impedimetry, and potentiometry have been developed [20-22]. Recently, our group developed a label-free potentiometric aptasensing method for the detection of Listeria monocytogenes in a homogeneous solution [23], based on the polycation-sensitive membrane electrode using protamine as an indicator. However, for that method, other bacteria with negative charges may interfere with the potential response of protamine. Additionally, the polycation-sensitive membrane electrode may suffer from problems of strong potential drifts, since the extraction of polycation into the membrane is an irreversible process. The purpose of this work was to develop a new method for the potentiometric detection of bacteria, which could not only eliminate sample interferences but also show stable and reversible potential responses.

Herein, we present a novel potentiometric aptasensing strategy for the detection of $V$. alginolyticus based on DNA nanostructure-modified magnetic beads for signal amplification and magnetic separation, and on a solid-contact polycation-sensitive membrane electrode for reversible potential detection via chronopotentiometry. In the presence of V. alginolyticus, the DNA nanostructure-modified magnetic beads can be disassembled, which is induced by the specific binding interactions between the target bacterial cells and the aptamer molecules in the DNA nanostrutures. After magnetic separation, the change in the charge or DNA concentration on the magnetic beads can be chronopotentiometrially detected by the solid-contact polycation-sensitive electrode using protamine as an indicator based on the electrostatic interaction between DNA and protamine.

\section{Materials and Methods}

\subsection{Materials}

High-molecular-weight poly(vinyl chloride) (PVC), 2-nitrophenyl octyl ether (o-NPOE), tetradodecylammonium chloride (TDDACl), dinonylnaphthalene sulfonic acid (DNNS, $50 \mathrm{wt} \%$ solution in heptanes), tris (hydroxymethyl)-aminomethane (Tris), protamine sulfate salt, and ionic liquid (IL, 1-butyl-3-methyl-imidazolium tetrafluoroborate) were purchased from Sigma-Aldrich. Carboxylic-multiwall carbon nanotubes (MWCNTs) were obtained from Nanjing XFNANO Materials Technology Co. Ltd. (Nanjing, China). The lipophilic salt DNNS-TDDA was synthesized as described before [24]. The magnetic beads $(1 \mu \mathrm{m}$ in diameter) were purchased from Bio Canal Co. Ltd. (Wuxi, China). Bacterial strains for V. alginolyticus 1.1587 and Aeromonas hydrophila 1.172 were purchased from Yudingxinjie Technology Co. Ltd. (Beijing, China). Bacterial strains for Escherichia coli (E. coli) ATCC 27853 and Staphylococcus aureus 08032813 were kindly provided from the Biotechnology Lab of Binzhou Medical University. The number of colony-forming units per $\mathrm{mL}^{(\mathrm{CFU} \mathrm{mL}}{ }^{-1}$ ) for each bacteria culture was determined by the surface plate counting method. The aptamer used in this work for the detection of $V$. alginolyticus was selected by Zheng et al. [3]. The sequences of the aptamer DNA and other DNA are shown in Table 1. All the sequences were synthesized by Shanghai Sangon Biotechnology Co. Ltd. (Shanghai, China). The buffer for DNA hybridization contained $100 \mathrm{mM} \mathrm{NaCl}$, $5 \mathrm{mM} \mathrm{KCl}, 50 \mathrm{mM}$ Tris- $\mathrm{HCl}$, and $1 \mathrm{mM} \mathrm{MgCl} 2(\mathrm{pH}=7.4)$.

Table 1. Sequences of the oligonucleotides used in this work.

\begin{tabular}{ll}
\hline Oligonucleotide & Sequence \\
\hline Aptamer DNA & 5'-TCAGTCGCTTCGCCGTCTCCTTCAGCCGGGGTGGTCAGTAGGA $^{\text {GCAGCACAAGAGGGAGACCCCAGAGGG-3' [3] }}$ \\
\hline Capture DNA & $5^{\prime}$-TTTTTCCCTCTGGGGTCTCCC-3' (modified with biotin at 5' terminal end) \\
\hline H 1 DNA & $5^{\prime}$-CGGCGAAGCGACTGACAAAGTCTAGTCGCT-3' \\
\hline H 2 DNA & $5^{\prime}$-TCAGTCGCTTCGCCGAGCGACTAGACTTTG-3' \\
\hline Random DNA & $5^{\prime}$-GAGTAGTTCGTG GCCTAG-3' \\
\hline
\end{tabular}




\subsection{Synthesis of the DNA Nanostructure-Modified Magnetic Beads}

All the oligonucleotides were kept at $95^{\circ} \mathrm{C}$ for $2 \mathrm{~min}$ and then cooled at room temperature for $1 \mathrm{~h}$ before use [25-27]. The DNA nanostructure-modified magnetic beads were prepared as described before [28]. The capture DNA modified magnetic beads were obtained by incubating $150 \mu \mathrm{L}$ of $5^{\prime}$-biotin-modified capture DNA fragments $(3 \mu \mathrm{M})$ with $150 \mu \mathrm{L}$ of streptavidin modified magnetic beads $\left(10 \mathrm{mg} \cdot \mathrm{mL}^{-1}\right)$ via shaking for $0.5 \mathrm{~h}$. After magnetic separation and washing with buffer, the capture DNA modified magnetic beads were incubated with $150 \mu \mathrm{L}$ of aptamer DNA fragments $(3 \mu \mathrm{M})$ via shaking for $1 \mathrm{~h}$, and the capture/aptamer DNA modified magnetic beads were thus obtained. The H1/H2 DNA complexes were prepared by incubating $150 \mu \mathrm{L}$ of H1 DNA fragments $(3 \mu \mathrm{M})$ with $150 \mu \mathrm{L}$ of $\mathrm{H} 2 \mathrm{DNA}$ fragments $(3 \mu \mathrm{M})$ via shaking for $1 \mathrm{~h}$. The H1/H2 DNA complexes $(150 \mu \mathrm{L})$ were then incubated with $150 \mu \mathrm{L}$ of capture/aptamer DNA modified magnetic beads with $1 \mathrm{~h}$ shaking. After magnetic separation and washing with buffer, the DNA nanostructure-modified magnetic beads were obtained and re-dispersed in $150 \mu \mathrm{L}$ of buffer solution. For the detection of bacteria, $40 \mu \mathrm{L}$ of the prepared DNA nanostructure-modified magnetic bead solution $\left(10 \mathrm{mg} \cdot \mathrm{mL}^{-1}\right)$ were used.

\subsection{Preparation of the Solid-Contact Polycation-Sensitive Electrode}

Prior to modification, the glassy carbon electrode (GCE, $3 \mathrm{~mm}$ in diameter) was polished with emery paper and alumina slurries followed by rinsing thoroughly with ultrapure water. The electrode was successively ultrasonicated in water and ethanol, and then allowed to dry at room temperature.

A mixture of $5 \mathrm{mg}$ of MWCNTs and $1 \mu \mathrm{L}$ of IL was ground in an agate mortar for $10 \mathrm{~min}$ [29], and then dispersed in $1 \mathrm{~mL}$ of ultrapure water with ultra-sonication to obtain a $5 \mathrm{mg} \cdot \mathrm{mL}^{-1}$ suspension solution. Twenty microliters of the MWCNT-IL suspension solution was coated onto the surface of the GCE and allowed to dry under an infrared lamp.

The polycation-sensitive membrane contained $10.0 \mathrm{wt} \%$ DNNS-TDDA, $60.0 \mathrm{wt} \% o-\mathrm{NPOE}$, and $30.0 \mathrm{wt} \%$ PVC. One hundred milligrams of the membrane components were dissolved in $800 \mu \mathrm{L}$ of tetrahydrofuran (THF). Eighty microliters of the membrane solution were coated onto the MWCNT-IL modified GCE. After the evaporation of THF, the prepared solid-contact polycation-sensitive electrodes were conditioned in $10 \mathrm{mM} \mathrm{NaCl}$ for at least $12 \mathrm{~h}$ before use, and kept in the conditioning solution when not in use.

\subsection{Determination of V. alginolyticus via Chronopotentiometry}

Forty microliters of DNA nanostructure-modified magnetic beads were mixed with $50 \mu \mathrm{L}$ of $V$. alginolyticus at different concentrations at room temperature for $30 \mathrm{~min}$. After magnetic separation, the resulting magnetic beads were then incubated with $7.5 \mu \mathrm{L}$ of $1 \mathrm{mg} \cdot \mathrm{mL}^{-1}$ protamine. The unreacted protamine after magnetic separation was added into $1.5 \mathrm{~mL}$ of $0.01 \mathrm{M} \mathrm{NaCl}$ and detected by the solid-contact polycation-sensitive electrode via chronopotentiometry.

Chronopotentiometry was performed by using a CHI-760C electrochemical workstation (Chenhua Corp., Shanghai, China) with a conventional three-electrode system comprising the proposed solid-contact polycation-sensitive membrane electrode as a working electrode, a platinum wire as counter electrode, and an $\mathrm{Ag} / \mathrm{AgCl}$ electrode (saturated $\mathrm{KCl}$ ) as a reference electrode. During the chronopotentiometric experiments, an external cathodic current of $5 \mu \mathrm{A}$ with a duration of $1 \mathrm{~s}$ was used to extract protamine into the polycation-sensitive membrane. The solid-contact polycation-sensitive membrane electrode was refreshed under a controlled voltage at the open-circuit potential in the absence of protamine with a recovery time of $180 \mathrm{~s}$ for multiple consecutive measurements. The difference between the potentials measured at $0.5 \mathrm{~s}$ after applying the current in the absence and presence of $V$. alginolyticus was used for quantification. 


\section{Results and Discussion}

\subsection{Sensing Principle}

Figure 1 shows the principle for the potentiometric aptasensing of $V$. alginolyticus based on DNA nanostructure-modified magnetic beads. The capture DNA was immobilized on the surface of the magnetic beads via the strong streptavidin-biotin interaction. The aptamer and H1/H2 DNA hybridize successively with the capture DNA through the complementary base-pairing reactions to form the DNA nanostructure-modified magnetic beads. In the presence of the target, the aptamer on the DNA nanostructure-modified magnetic beads specifically binds to the target, which leads to the disassembly of the DNA nanostructures and subsequently influences the charge or DNA concentration on the magnetic beads [28]. This aptamer/target binding event can be detected by the solid-contact polycation-sensitive electrode using protamine as an indicator, based on the electrostatic interaction between the DNA nanostructures and protamine.

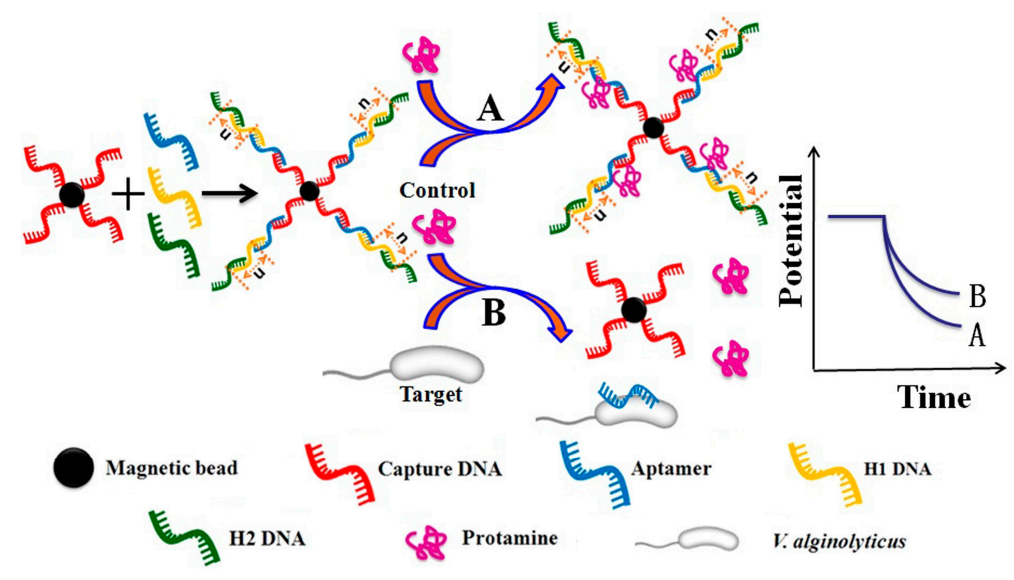

Figure 1. Schematic illustration of potentiometric aptasensing of $V$. alginolyticus based on DNA nanostructure-modified magnetic beads for (A) a control and (B) a given target assay.

Figure 2 shows the principle for the detection of protamine with the polycation-sensitive electrode based on the MWCNT-IL composite as solid contact via chronopotentiometry. The application of the imidazolium-based IL is to prevent the formation of agglomerates of MWCNTs through cation- $\pi$ interactions between the imidazolium cation and the $\pi$-electrons of nanotubes [30], while MWCNTs are used to decrease the charge transfer resistance and improve the electrical conductivity at the interface between the GCE and the polycation-sensitive membrane [31]. Under zero current conditions, there is no potential response to protamine, due to the presence of the neutral lipophilic salt DNNS-TDDA in the polycation-sensitive membrane. When a constant cathodic current is applied, there is a net flux of polycation in the direction of the membrane phase, since protamine can electrostatically interact with DNNS in the membrane phase to form the cooperative ion pairs [32]. Additionally, in order to obtain the reversible potential response, protamine can be removed from the polycation-sensitive membrane by applying a controlled voltage at the open-circuit potential. 


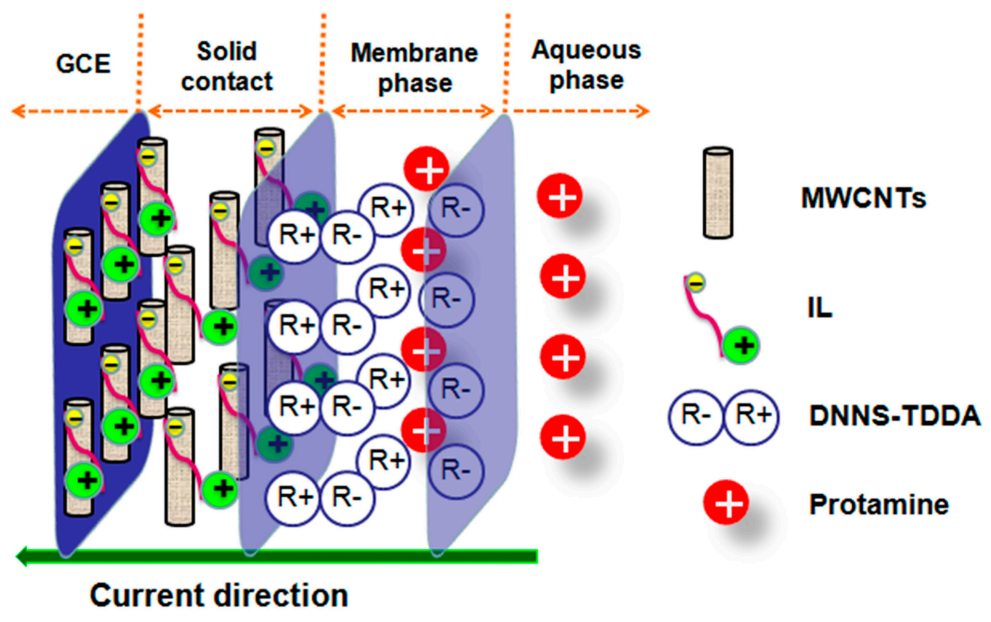

Figure 2. Schematic diagram of the polycation-sensitive electrode based on a MWCNT-IL composite as a solid contact for the chronopotentiometric detection of protamine.

\subsection{Optimization of Protamine Concentration}

Since protamine was used as an indicator to detect the change in the DNA concentration on the DNA nanostructure-modified magnetic beads induced by $V$. alginolyticus, the effect of protamine concentration was investigated. Figure $3 \mathrm{~A}$ show s the potentiometric responses of the solid-contact polycation-sensitive membrane electrode under an external cathodic current of $5 \mu \mathrm{A}$ with a duration of $1 \mathrm{~s}$. It can be seen that the potential response of the polycation-sensitive membrane electrode in the presence of protamine is larger than that in the absence of protamine, which indicates that protamine is extracted into the polycation-sensitive membrane. Figure 3B shows the curve of the potential change of the membrane electrode vs. the concentration of protamine. When the concentration of protamine is $5 \mu \mathrm{g} \cdot \mathrm{mL}^{-1}$, the potential change is up to $30 \mathrm{mV}$. Considering the subsequent electrostatic interaction between the DNA nanostructures and protamine and the sensitivity of the polycation-sensitive membrane electrode, $5 \mu \mathrm{g} \cdot \mathrm{mL}^{-1}$ protamine was selected for further experiments.
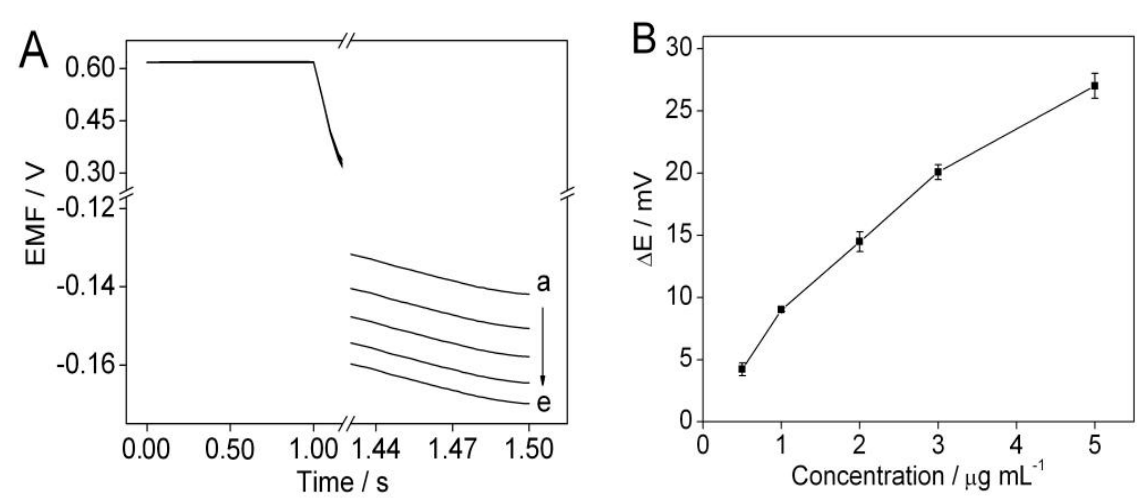

Figure 3. (A) Potentiometric responses of the solid-contact polycation-sensitive membrane electrode in $1.5 \mathrm{~mL}$ of $0.01 \mathrm{M}$ sodium chloride solution with different protamine concentrations of (a-e) $5 ; 3 ; 2 ; 0.5 ; 0 \mu \mathrm{g} \cdot \mathrm{mL}^{-1}$. (B) Plot shows potential changes over the protamine concentration range of $0-5 \mu \mathrm{g} \cdot \mathrm{mL}^{-1}$. Error bars represent one standard deviation for three measurements.

\subsection{Optimization of the Amount of the DNA Nanostructure-Modified Magnetic Beads}

The influence of the amount of the DNA nanostructure-modified magnetic beads on the potential response to protamine of the solid-contact polycation-sensitive membrane electrode was investigated. As shown in Figure 4A, there is an obvious potential change in the presence of the 
DNA nanostructure-modified magnetic beads, which is due to the electrostatic interaction between the DNA nanostructures and protamine. Additionally, as shown in Figure 4B, the potential change increases as the amount of DNA nanostructure-modified magnetic beads increases up to $40 \mu \mathrm{L}$, and thereafter remains almost constant. Therefore, a volume of $40 \mu \mathrm{L}$ was used as the amount of the DNA nanostructure-modified magnetic beads for further study.
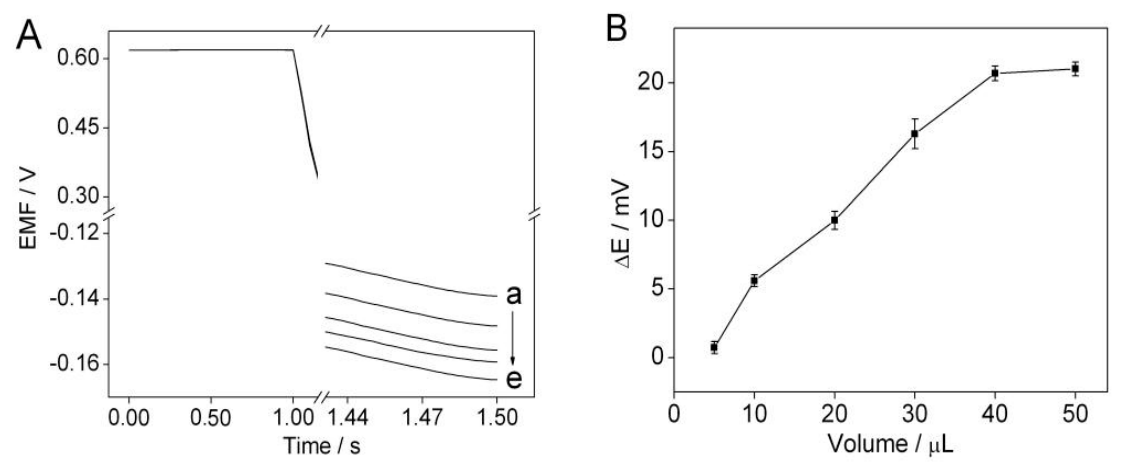

Figure 4. (A) Potentiometric responses of the solid-contact polycation-sensitive membrane electrode in $1.5 \mathrm{~mL}$ of $0.01 \mathrm{M}$ sodium chloride solution with $5 \mu \mathrm{g} \cdot \mathrm{mL}^{-1}$ protamine in the presence of DNA nanostructure-modified magnetic beads with different volumes of (a-e) $0 ; 5 ; 10 ; 30 ; 40 \mu \mathrm{L}$. (B) Plot shows the potential changes over the volume range of $0-50 \mu \mathrm{L}$ for the DNA nanostructure-modified magnetic beads. Error bars represent one standard deviation for three measurements.

\subsection{The Detection of V. alginolyticus via Chronopotentiometry}

Under the optimal experimental conditions, the potentiometric responses to $V$. alginolyticus were tested by using the solid-contact polycation-sensitive membrane electrode via chronopotentiometry. As shown in Figure 5A, the potential response $V$. alginolyticus increases with increasing the concentration of $V$. alginolyticus, which indicates that the disassembly of the DNA nanostructures results in the decrease in the charge or DNA concentration on the surface of the modified magnetic beads. Figure 5B shows the calibration curve of the potentiometric aptasensing assay. It can be seen that the linear range for the proposed potentiometric aptasensing assay is $10-100 \mathrm{CFU} \mathrm{mL}^{-1}$, and the

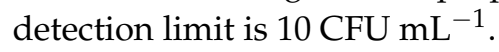
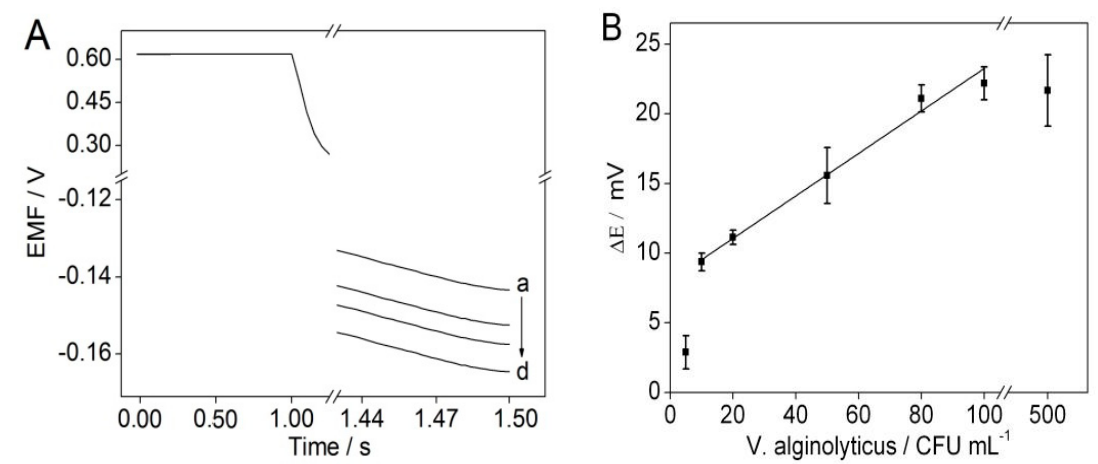

Figure 5. (A) Potentiometric responses of the solid-contact polycation-sensitive membrane electrode in $1.5 \mathrm{~mL}$ of $0.01 \mathrm{M}$ sodium chloride solution with $5 \mu \mathrm{g} \cdot \mathrm{mL}^{-1}$ protamine and $40 \mu \mathrm{L}$ DNA nanostructure-modified magnetic beads in the presence of (a-d) 100; 50; 10;0 CFU mL $\mathrm{mL}^{-1} \mathrm{~V}$. alginolyticus. (B) Plot shows the potential changes over the V. alginolyticus concentration range of 5-500 CFU mL ${ }^{-1}$. Error bars represent one standard deviation for three measurements. 


\subsection{Specificity Test}

In order to test the specificity of the potentiometric aptasensing method for the detection of $V$. alginolyticus, four bacterial strains including V. alginolyticus, E. coli, Staphylococcus aureus, and Aeromonas hydrophila were tested. As shown in Figure 6A, no obvious potential changes are observed for these bacteria. This indicates that the proposed method for the detection of $V$. alginolyticus has a good specificity. Additionally, the influence of the random DNA on the potential response was also investigated (Figure 6B). The results indicate that the DNA nanostructures containing the random DNA would not induce any significant change in the potential response.
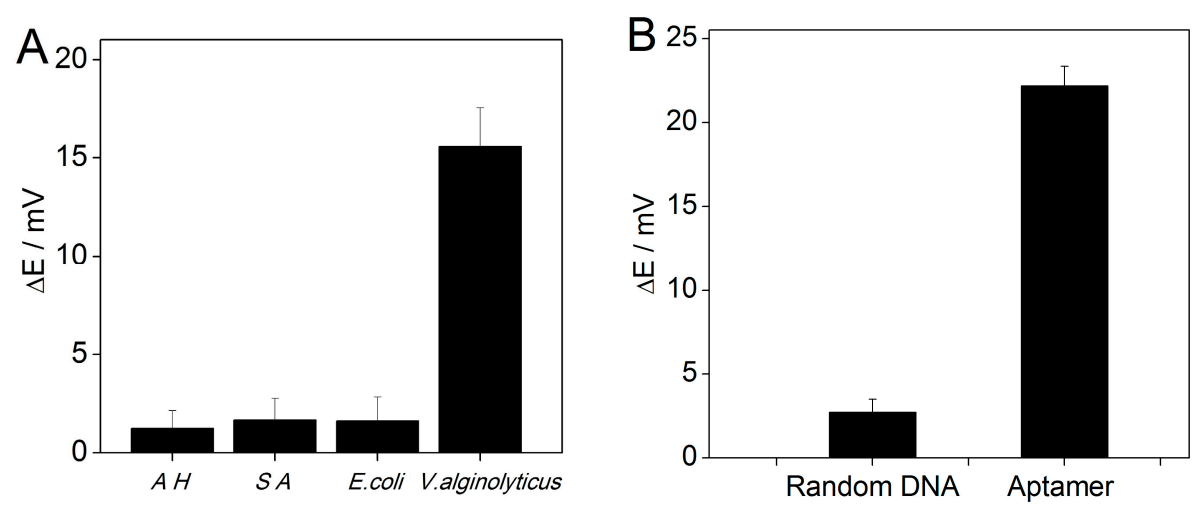

Figure 6. (A) Potential changes in the presence of $500 \mathrm{CFU} \mathrm{mL} \mathrm{m}^{-1}$ Aeromonas hydrophila (AH),

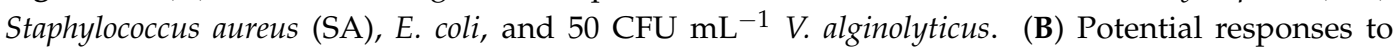
$100 \mathrm{CFU} \mathrm{mL} \mathrm{m}^{-1} \mathrm{~V}$. alginolyticus using the aptamer and random DNA-based DNA nanostructures. Error bars represent one standard deviation for three measurements.

\section{Conclusions}

This work demonstrates a potentiometric aptasensing assay using signal amplification and magnetic separation strategies. The method is based on the DNA nanostructure-modified magnetic beads and the solid-contact polycation-sensitive membrane electrode for the reversible chronopotentiometric detection of $V$. alginolyticus. The proposed method shows a linear concentration range of $10-100 \mathrm{CFU} \mathrm{mL}{ }^{-1}$ with a detection limit of $10 \mathrm{CFU} \mathrm{mL} \mathrm{m}^{-1}$, and a good specificity for the detection of $V$. alginolyticus. The proposed strategy can be used for the detection of other microorganisms by changing the aptamers in the DNA nanostructures.

Acknowledgments: This work was financially supported by the Strategic Priority Research Program of the Chinese Academy of Sciences (XDA11020702), the National Natural Science Foundation of China (41176081, 21475148 and 21575158), and the Taishan Scholar Program of Shandong Province.

Author Contributions: Jiawang Ding and Wei Qin conceived and designed the experiments; Guangtao Zhao and Han Yu performed the experiments; Jiawang Ding and Guangtao Zhao analyzed the data, Guangtao Zhao, Tanji Yin, and Wei Qin wrote the paper.

Conflicts of Interest: The authors declare no conflict of interest.

\section{References}

1. Zhao, Z.; Zhang, L.P.; Ren, C.H.; Zhao, J.J.; Chen, C.; Jiang, X.; Luo, P.; Hu, C.Q. Autophagy is induced by the type III secretion system of Vibrio alginolyticus in several mammalian cell lines. Arch. Microbiol. 2011, 193, 53-61. [CrossRef] [PubMed]

2. Jang, I.K.; Qiao, G.; Kim, S.K. Effect of multiple infections with white spot syndrome virus and Vibrio anguillarum on Pacific white shrimp Litopenaeus vannamei (L.): Mortality and viral replication. J. Fish Dis. 2014, 37, 911-920. [CrossRef] [PubMed] 
3. Zheng, J.; Tang, X.M.; Wu, R.X.; Yan, Q.P.; Tang, H.; Luo, J.W.; Niu, S.F.; Qu, Y.K.; Sun, L.W. Identification and characteristics of aptamers against inactivated Vibrio alginolyticus. LWT-Food. Sci. Technol. 2015, 64, 1138-1142. [CrossRef]

4. Xu, Y.G.; Cui, L.C.; Liu, Z.M.; Li, D.D.; Li, S.L.; Zhao, M.C. Simultaneous detection of five pathogenic Vibrio species in seafood by a multiplex polymerase chain reaction coupled with high performance liquid chromatography assay. Food Control 2015, 53, 109-116. [CrossRef]

5. Durai, S.; Pandian, S.K.; Balamurugan, K. Establishment of a Caenorhabditis elegans infection model for Vibrio alginolyticus. J. Basic Microb. 2011, 51, 243-252. [CrossRef] [PubMed]

6. Liu, Y.; Hu, J.; Sun, J.S.; Li, Y.; Xue, S.X.; Chen, X.Q.; Li, X.S.; Du, G.X. Facile synthesis of multifunctional multi-walled carbon nanotube for pathogen Vibrio alginolyticus detection in fishery and environmental samples. Talanta 2014, 128, 311-318. [CrossRef] [PubMed]

7. Fukui, Y.; Sawabe, T. Improved one-step colony PCR detection of Vibrio harveyi. Microbes. Environ. 2007, 1, 1-10. [CrossRef]

8. Xie, Z.Y.; Ke, S.W.; Hu, C.Q.; Zhu, Z.X.; Wang, S.F.; Zhou, Y.C. First characterization of bacterial pathogen, Vibrio alginolyticus, for porites and rewsi white syndrome in the South China Sea. PLoS ONE 2013, 8, e75425.

9. Wei, S.; Zhao, H.; Xian, Y.Y.; Hussain, M.; Wu, X.Y. Multiplex PCR assays for the detection of Vibrio alginolyticus, Vibrio parahaemolyticus, Vibrio vulnificus, and Vibrio cholerae with an internal amplification control. Diagn. Micr. Infec. Dis. 2014, 79, 115-118. [CrossRef] [PubMed]

10. Zhen, X.W.; Zheng, Q.Y.; Fu, J.F.; Xu, J.Y.; Cao, J.J. A raid multiplex PCR-DHPLC method of detection and identification of pathogenic bacteria in aquatic products. J. Food Saf. 2015, 35, 50-58. [CrossRef]

11. Citartan, M.; Ch'ng, E.S.; Rozhdestvensky, T.S.; Tang, T.H. Aptamers as the 'capturing' agents in aptamer-based capture assays. Microchem. J. 2016, 128, 187-197. [CrossRef]

12. Zhang, Z.P.; Tao, C.C. Rational design of a mismatched aptamer-DNA duplex probe to improve the analytical performance of electrochemical aptamer sensors. Electrochim. Acta 2016, 209, 479-485. [CrossRef]

13. Wu, D.; Wang, Y.G.; Zhang, Y.; Ma, H.M.; Pang, X.H.; Hu, L.H.; Du, B.; Wei, Q. Facile fabrication of an electrochemical aptasensor based on magnetic electrode by using streptavidin modified magnetic beads for sensitive and specific detection of $\mathrm{Hg}^{2+}$. Biosens. Bioelectron. 2016, 82, 9-13. [CrossRef] [PubMed]

14. Ma, C.; Liu, H.Y.; Tian, T.; Song, X.R.; Yu, J.G.; Yan, M. A simple and rapid detection assay for peptides based on the specific recognition of aptamer and signal amplification of hybridization chain reaction. Biosens. Bioelectron. 2016, 83, 15-18. [CrossRef] [PubMed]

15. Numnuam, A.; Chumbimuni-Torres, K.Y.; Xiang, Y.; Bash, R.; Thavarungkul, P.; Kanatharana, P.; Pretsch, E.; Wang, J.; Bakker, E. Aptamer-based potentiometric measurements of proteins using ion-selective microelectrodes. Anal. Chem. 2008, 80, 707-712. [CrossRef] [PubMed]

16. Wang, Q.Y.; Kang, Y.J. Bioprobes based on aptamer and silica fluorescent nanoparticles for bacteria Salmonella typhimurium detection. Nanoscale Res. Lett. 2016, 11, 1-9. [CrossRef] [PubMed]

17. Singh, P.; Gupta, R.; Sinha, M.; Kumar, R.; Bhalla, V. MoS 2 based digital response platform for aptamer based fluorescent detection of pathogens. Microchim. Acta 2016, 183, 1501-1506. [CrossRef]

18. Chandola, C.; Kalme, S.; Casteleijn, M.; Urtti, A.; Neerathilin, M. Application of aptamers in diagnostics, drug-delivery and imaging. J. Biosci. 2016, 41, 535-561. [CrossRef] [PubMed]

19. Shen, H.J.; Wang, J.; Liu, H.Y.; Li, Z.H.; Jiang, F.L.; Wang, F.B.; Yuan, Q. Rapid and selective detection of pathogenic bacteria in bloodstream infections with aptamer-based recognition. ACS Appl. Mater. Interfaces 2016, 8, 19371-19378. [CrossRef] [PubMed]

20. Escamilla-Gómez, V.; Campuzano, S.; Pedrero, M.; Pingarrón, J.M. Immunosensor for the determination of Staphylococcus aureus using a tyrosinase-mercaptopropionic acid modified electrode as an amperometric transducer. Anal. Bioanal. Chem. 2008, 391, 837-845. [CrossRef] [PubMed]

21. Labib, M.; Zamay, A.S.; Kolovskaya, O.S.; Reshetneva, I.T.; Zamay, G.S.; Kibbee, R.J.; Sattar, S.A.; Zamay, T.N.; Berezovski, M.V. Aptamer-based impedimetric sensor for bacterial typing. Anal. Chem. 2012, 84, 8114-8117. [CrossRef] [PubMed]

22. Hernández, R.; Vallés, C.; Benito, A.M.; Maser, W.K.; Rius, F.X.; Riu, J. Graphene-based potentiometric biosensor for the immediate detection of living bacteria. Biosens. Bioelectron. 2014, 54, 553-557. [CrossRef] [PubMed]

23. Ding, J.W.; Lei, J.H.; Ma, X.; Gong, J.; Qin, W. Potentiometric aptasensing of Listeria monocytogenes using protamine as an indicator. Anal. Chem. 2014, 86, 9412-9416. [CrossRef] [PubMed] 
24. Shvarev, A.; Bakker, E. Reversible electrochemical detection of non-electroactive polyions. J. Am. Chem. Soc. 2003, 125, 11192-11193. [CrossRef] [PubMed]

25. Rodriguez, M.C.; Kawde, A.N.; Wang, J. Aptamer biosensor for label-free impedance spectroscopy detection of proteins based on recognition-induced switching of the surface charge. Chem. Commun. 2005, 34, 4267-4269. [CrossRef] [PubMed]

26. Cheng, A.K.H.; Ge, B.X.; Yu, H.Z. Aptamer-based biosensors for label-free voltammetric detection of lysozyme. Anal. Chem. 2007, 79, 5158-5164. [CrossRef] [PubMed]

27. Zhao, Q.; Li, X.F.; Shao, Y.H.; Le, X.C. Aptamer-based affinity chromatographic assays for thrombin. Anal. Chem. 2008, 80, 7586-7593. [CrossRef] [PubMed]

28. Ding, J.W.; Gu, Y.; Li, F.; Zhang, H.X.; Qin, W. DNA nanostructure-based magnetic beads for potentiometric aptasensing. Anal. Chem. 2015, 87, 6465-6469. [CrossRef] [PubMed]

29. Tu, W.W.; Lei, J.P.; Ju, H.X. Functionalization of carbon nanotubes with water-insoluble porphyrin in ionic liquid: Direct electrochemistry and highly sensitive amperometric biosensing for trichloroacetic acid. Chem. Eur. J. 2009, 15, 779-784. [CrossRef] [PubMed]

30. Ye, Y.S.; Wang, H.; Bi, S.G.; Xue, Y.; Xue, Z.G.; Liao, Y.G.; Zhou, X.P.; Xie, X.L.; Mai, Y.W. Enhanced ion transport in polymer-ionic liquid electrolytes containing ionic liquid-functionalized nanostructured carbon materials. Carbon 2015, 86, 86-97. [CrossRef]

31. Wardak, C. Solid contact cadmium ion-selective electrode based on ionic liquid and carbon nanotubes. Sens. Actuators B Chem. 2015, 209, 131-137. [CrossRef]

32. Ramamurthy, N.; Baliga, N.; Wahr, J.A.; Schaller, U.; Yang, V.C.; Meyerhoff, M.E. Improved protamine- sensitive membrane electrode for monitoring heparin concentrations in whole blood via protamine titration. Clin. Chem. 1998, 44, 606-613. [PubMed]

(C) 2016 by the authors; licensee MDPI, Basel, Switzerland. This article is an open access article distributed under the terms and conditions of the Creative Commons Attribution (CC-BY) license (http:/ / creativecommons.org/licenses/by/4.0/). 